\title{
Covariance in water- and nutrient budgets of Dutch peat polders: what governs nutrient retention?
}

\author{
Jan E. Vermaat • Fritz Hellmann
}

Received: 15 April 2009/Accepted: 24 November 2009/Published online: 5 December 2009

(C) The Author(s) 2009. This article is published with open access at Springerlink.com

\begin{abstract}
Water and nutrient budgets were constructed for 13 low-lying peat polders in the Netherlands that varied in elevation relative to sea level $(-0.2$ to $-2.4 \mathrm{~m}$ below sea level), land use $(7-70 \%$ of the total polder area covered by agriculture; largely dairy farming), and surface water prevalence (6-43\%). Water balances were verified with chloride budgets and accepted when both met the criterion (total inflows - total outflows)/(total inflows) $<0.05$. Apart from precipitation and evapotranspiration (overall means 913 vs. $600 \mathrm{~mm}$ ), in- and outlet (171 vs. $420 \mathrm{~mm}$ ) as well as in- and outward seepage (137 vs. $174 \mathrm{~mm}$ ) were important items in the water budgets. Nutrient budgets, however, were dominated by terms related to agricultural land use ( $\sim 60 \%$ of all inputs, $90 \%$ of $\mathrm{N}$-removal and $80 \%$ of $\mathrm{P}$ removal) rather than water fluxes $(8 \%$ and $5 \%$ of $\mathrm{N}$ and $\mathrm{P}$ inputs; 6 and $18 \%$ of outputs). After agriculture (200 kg N ha $\mathrm{kg}^{-1}$ ), mineralisation of the peat soil and atmospheric deposition appear to be important inputs (about 94 and $21 \mathrm{~kg} \mathrm{~N} \mathrm{ha}^{-1} \mathrm{y}^{-1}$ ). Major output terms were agricultural output $\left(209 \mathrm{~kg} \mathrm{~N} \mathrm{ha}^{-1} \mathrm{y}^{-1}\right)$ and denitrification $\left(95 \mathrm{~kg} \mathrm{~N} \mathrm{ha}^{-1} \mathrm{y}^{-1}\right)$. The average
\end{abstract}

J. E. Vermaat $(\bowtie) \cdot$ F. Hellmann

Institute for Environmental Studies, Vrije Universiteit

Amsterdam, De Boelelaan 1087, 1081 HV, Amsterdam,

The Netherlands

e-mail: jan.vermaat@ivm.vu.nl
$\mathrm{N}$ budget was in balance (difference $\sim 1 \mathrm{~kg} \mathrm{~N}^{-1}$ $\mathrm{y}^{-1}$ ), whereas $\mathrm{P}$ accumulated in most polders, particularly those under agriculture. The mean $\mathrm{P}$ surplus (15 kg P ha $\mathrm{y}^{-1}$ in the 9 mainly agricultural polders) corresponds well with the accumulated difference observed elsewhere $\left(700 \mathrm{~kg} \mathrm{P} \mathrm{ha}{ }^{-1}\right.$ in the upper $50 \mathrm{~cm}$ in a nature reserve versus 1400 under agriculture) after over 50 years of dairy farming. Bulk retention of $\mathrm{N}$ and $\mathrm{P}$ in these polders is taking place in the peat soil, through temporary sorption to the matrix and $\mathrm{N}$ is lost through denitrification. In a principal components analysis combining land use, landscape pattern, water balance and nutrient budget terms, the three-first principal components explained $63 \%$ of the variability. The first component (PC) correlated strongly with the percentage of land under agriculture $(r=0.82)$ and negatively with the percentage covered by surface water $(r=-0.74)$. Most input and output terms of the nitrogen budget also correlated with this PC. The second PC covaried distinctly with the total area of a polder $(r=-0.79)$ and human population density at municipality level $(r=0.75)$. Phosphorus loads in inlet and outlet water correlated with this PC. This suggests that the variability in nutrient budgets among polders is largely governed by agricultural land use.

Keywords Wetlands - Water management . Mineralisation · Land use · Fertilization · Subsidence 


\section{Introduction}

The presently low-lying peatlands of The Netherlands have been reclaimed and intensively used since the Middle Ages (Verhoeven 1992). Reclamation created a regular pattern of dikes, ditches and farmland (e.g. Bakker et al. 1994; Nol et al. 2008), of which the absolute level has been falling due to mineralisation of the peat. Comparable peatland polders have been reclaimed and drained around the world (e.g. Keddy 2000; Charlier et al. 2005; Verhoeven and Setter 2009). The process of subsidence has probably accelerated since the nineteen-fifties when mechanisation of agriculture demanded lower water tables (Schothorst 1977; Nieuwenhuis and Schokking 1997). As a consequence, water level in Dutch peatlands is managed with pumping stations in independent polder units, each with its own distribution of land and water, intensity of land use, paved area and water level (e.g. Vermaat et al. 2007). Surface water quality in these polders is probably strongly affected by the intensity of agricultural land use (Best and Jacobs 2001; Van Beek et al. 2004a, 2007), but peat mineralisation may also contribute a substantial nutrient load (Schothorst 1977; Van Beek et al. 2007), and so may the inlet of river Rhine water during periods of water shortage in summer (Lamers et al. 2002). Together, these components of water and nutrient balances and their interactions may be affected by foreseen climate change, where summer water shortage and winter precipitation are foreseen to increase (Van den Hurk et al. 2006). For example, rewetting, or the raising of the water table to counteract subsidence in a polder may enhance nutrient release and thus internal loading (Richardson 1985; Van Dijk et al. 2004), whereas the resulting expansion of reedbeds may enhance evapotranspiration thus reducing an anticipated rise in water table (Vernooij and Vermaat 2009). Nutrient dynamics in wetland soils and aquatic sediments are complex. Those of nitrogen are often dominated by microbial processes, e.g. fixation, nitrification and denitrification (Barnard et al. 2005), whereas those of phosphorus are governed by sorption and precipitation mechanisms (with $\mathrm{Ca}, \mathrm{Fe}, \mathrm{Al}$; e.g. Richardson 1985; Qualls and Richardson 1995; Roden and Edmonds 1997; Bridgham et al. 2001, Zak et al. 2004) with oxygen availability, redox potential and $\mathrm{pH}$ often as forcing factors (Heathwaite 1990; Best and Jacobs 2001; Lamers et al. 2002; Van Dijk et al. 2004).

Variation in reclamation and land use history as well as hydrogeology has led to variation among polders in the size distribution and pattern of water bodies: some polders have numerous parallel narrow ditches, others have a more reticulate mosaic pattern, and again others have wider expanses of open water in broads and turbaries due to peat excavation (e.g. Bakker et al. 1994; Vermaat et al. 2007, 2008; Nol et al. 2008), or larger lakes due to subsequent erosion (Verhoeven 1992; Nieuwenhuis and Schokking 1997). The banks of these water bodies form a network of littoral transitions between land and water. These narrow, linear wetlands are considered rich in specific biodiversity elements (Blomqvist et al. 2003a, b; Herzon and Helenius 2008), and are subject to intensive management (Best et al. 1995; Blomqvist et al. 2003a; Twisk et al. 2003). These ditch banks may well perform some of the highly valued services generally attributed to wetlands (e.g. Balmford et al. 2002; Brander et al. 2006), such as nutrient and carbon sequestration (Aerts 2000; OldeVenterink et al. 2003; Van Oene et al. 2001; Verhoeven et al. 2006), similar to buffer strips (Hefting et al. 2006). Hence, one could postulate that the density of the ditch drainage pattern may affect nutrient retention processes in these polders. These ditches then would operate in a manner similar to the wetlands and lakes that are assumed to maintain water quality in intensively exploited catchments (Verhoeven et al. 2006) provided they cover a sufficiently large proportion of the area (2-7\%). Nutrient retention, in this respect could be mediated by different processes, i.e. sequestration in soils but also ditch sediments, uptake by biota including crops and fodder, and $\mathrm{N}$ may be lost to the atmosphere through denitrification. Single-ditch in situ studies (Meuleman et al. 2004; Toet et al. 2005) suggest that polder ditches may retain substantial quantities of nutrients from the inflowing water, but only Van Beek et al. (2004a, 2007) have up-scaled this approach to one full polder subject to regular farming land use practice. Differences among polders in ditch pattern across the landscape, however, may be reflected in differences in nutrient dynamics.

We expanded the approach of Van Beek et al. (2004a, 2007) to cover a wider range of land use 
patterns and of surface water area and distribution pattern. We collected data from water boards, the national statistics depository and grey literature to construct water and nutrient budgets for individual, separately managed polder units and confront these with land use and landscape pattern statistics in search for patterns of joint variability. Our specific aims were, firstly, to assess covariance among water and nutrient budgets and land use in search for the primary drivers of variability among these polders in factors governing nutrient retention, and secondly, to explore the possible relation between nutrient retention processes and landscape pattern in the allocation of water as ditches and ponds in these polders. The latter would test for a possible buffering effect of these ditches and, extrapolating from Verhoeven et al. (2006), it will address a possible edge-area effect of ditches.

\section{Materials and methods}

A polder is treated here as one single hydrologically separated unit of land and water, irrespective of its actual size. It is connected to other surface water via pumping stations. Each polder unit contains the land and its underlying topsoil (down to about $1 \mathrm{~m}$; Van Beek et al. 2004a), and all surface water. It interfaces with deeper groundwater through upward and downward seepage, and with the atmosphere through precipitation, evapotranspiration and volatilization. Farming practice introduces and removes water and nutrients to this polder. Ditch sediment is considered a temporary store of matter outside the polder unit, and deeper soils and groundwater are also assumed to be external.

For each polder, water balances were compiled from internal water board and consultancy reports in the period from 1990 to 2005 (Table 1; Appendix). Chloride, total nitrogen and total phosphorus concentrations of surface and ground water (Tables 1, 2; Appendix) were obtained from the monitoring programs of water boards, and the national surface and ground water monitoring depositories (e.g. www.waterbase.nl and Griffioen et al. 2002). For precipitation, quality data were obtained from Van Drecht et al. (1996) and Fraters et al. (2004, 2007). Water balances were cross-checked for consistency with chloride mass balances and considered acceptable when the difference between summed inputs and outputs was $5 \%$ or less of the influx (Appendix). Revisions of seven balances were made after discussion with water board experts leading to adjustments in the chloride content of seepage (1 polder,Appendix), volumes of seepage water (5), the volumes of surface water pumped (3) and the chloride content of pumped surface water (2). No attempt was made to close the budgets for $\mathrm{N}$ and $\mathrm{P}$, since these should derive from the water balance. Land use data were obtained from the municipal statistics maintained by the national statistics service (www.cbs.nl; CBS 2000a; Table 3) and digital land use maps (CBS 2000b; Kadaster 2007).

We compiled data of sufficient quality for thirteen polders (Fig. 1; Appendix), varying in size $\left(2-141 \mathrm{~km}^{2}\right)$, elevation relative to sea level $(-0.2$ to $-2.4 \mathrm{~m}$ below Dutch Ordnance Survey Level), land use (0-95\% agriculture, generally dairy), and surface water prevalence (6-43\%). Covariance was analysed first with ordinary principal components analysis, whereas the different variables reflecting aspects of retention were further subjected to forward stepwise regression. All statistical analyses were carried out with SPSS v16.

\section{Results}

Overall, the water budgets of the studied polders had only minor remaining differences between the sums of inflows and outflows (on average $27 \mathrm{~mm}$, or $2 \%$ of a mean annual input of $1222 \mathrm{~mm}$ ). The average surplus in precipitation over evapotranspiration is compensated for by pumping more water out than into these polders, whereas upward and downward seepage, on average compensate each other (Fig. 2). These averages are underlain by substantial amongpolder variability. Upward seepage, for example, ranged between 0 and $423 \mathrm{~mm}$, downward seepage ranged between 0 and $803 \mathrm{~mm}$, depending on the position of a polder in the surrounding landscape: adjacent higher grounds lead to upward seepage, deeper neighbouring polders cause downward seepage. Precipitation ranged between 830 and $1114 \mathrm{~mm}$ across the polders, primarily because of spatial differences, but also because the data of different polders are available for different years (1990-2004). Observed rainfall in the polders corresponded well with the grand mean reported for these years in the 
Table 1 Annual water balance terms used, the range of estimated values among the 13 polders, their derivation and data sources used

\begin{tabular}{lll}
\hline Balance term & $\begin{array}{l}\text { Range } \\
(\mathrm{mm})\end{array}$ & Description, sources \\
\hline
\end{tabular}

Inputs

Precipitation

Upward, inward seepage

Inlet surface water

Agricultural inputs ${ }^{\mathrm{b}}$

Sewage works effluents, storm overflows and highway run-off ${ }^{\mathrm{b}}$

Outputs

Evapotranspiration

Downward, outward seepage

Outlet surface water

Agricultural outputs ${ }^{b}$

Difference between total inputs and outputs
830-1114 Obtained from internal water board balance reports ${ }^{\mathrm{a}}$. Generally interpolated with Thyssen-polygon weighing from nearby meteorological stations. Rainfall for a specific budget year and polder corresponded quite well with the means reported for the five main stations of the Royal Netherlands Meteorological Service (paired $t$-test: $p=0.13)$, but the explained variance was low $(0.23)$ due to two outliers: the Vlietpolder (+20\% compared to mean for 2000) and Staphorsterveld $(-10 \%$ compared to mean for 1999). The former lies in the Rijnland area, an exceptionally wet part of The Netherlands (Heijboer and Nellestijn 2002), the latter must have had a dry year locally. Without these two the correlation is better: $r^{2}=0.68$, $p<0.001$. The coefficient of variation in annual rainfall over the five main meteorological stations among the years studied here was $10 \%$. Chloride concentration for Vlietpolder from Van Beek et al. (2007), otherwise adjusted according to Barendregt et al. (1995) and Van Drecht et al. (1996) depending on distance to the sea

0-423 From adjacent higher grounds or water bodies. Obtained from water board balances, cross-validated and/or estimated from consultancy reports. Chloride concentration of seepage from water board estimates or Van Drecht et al. (1996)

0-755 From water board data. Generally derived from extrapolated pumping hour logs and full capacity rates of pumping stations. Chloride concentrations from monitoring programs of water boards

- $\quad$ Extrapolated from Van Beek et al. (2003, 2004) to specific land use characteristics of each polder. Witteveen and Bos estimated additional, unregistered water inlets by individual farmers for Ankeveen and Kortenhoef, but these were minor. Also the chloride content of agricultural in- and outputs is based on Van Beek et al. (2003, 2004)

- $\quad$ From budget of the water board. Only present in the Overwaard and Nederwaard of the Ablasserwaard. Chloride concentration based on Van Mossevelde et al. (2005; $488 \mathrm{mg} \mathrm{l}^{-1}$ in storm overflows). For these two polders we include a small entry covering chloride from highway run-off

514-687 Obtained from water board balances, which generally are extrapolated from a limited set of meteorological stations that measure Makkink evapotranspiration

0-803 Similar to upward seepage

115-730 See inlet surface water

- $\quad$ Output of agricultural products from the polder parcel (hay, milk, meat), see also inputs

0-5.2\% Annual net storage or loss not presented as a separate term, but used to assess the quality of the balance, in conjunction with the chloride balance. See text. Final differences are reported in Appendix

All are estimated in $\mathrm{mm} \mathrm{y}^{-1}$ and $10^{6} \mathrm{~m}^{3}$ polder $^{-1} \mathrm{y}^{-1}$. Chloride balances $\left(10^{3} \mathrm{~kg} \mathrm{y}^{-1}\right)$ use the same budget entries and are estimated from water fluxes and concentrations of inert chloride

${ }^{a}$ Water board reports and other data sources are specified in detail for each polder in Appendix

b These three terms were negligible in the water balances, but did contribute to the chloride budgets.Agriculture contributed inputs through manure and removed chloride with hay

Netherlands (Table 1), if the two extremes are excluded. Among-year variability in rainfall for the studied years was acceptable (coefficient of variability $=10 \%)$.
The average budget for $\mathrm{N}$ was in balance (Fig. 2, surpluses not significantly different from zero, $p=0.32)$ whereas the $\mathrm{P}$ budget displayed a net surplus ( $\sim 7 \mathrm{~kg} \mathrm{ha}^{-1} \mathrm{y}^{-1}$, or $23 \%$ of inputs, Fig. 2). 
Table 2 Annual nitrogen and phosphorus budget terms used, ranges observed, and their sources and derivation

\begin{tabular}{|c|c|c|}
\hline Balance term & Range & Description, sources \\
\hline \multicolumn{3}{|l|}{ Inputs } \\
\hline Precipitation & $\begin{array}{l}\text { N: } 14-32 \\
P: 0-3\end{array}$ & $\begin{array}{l}\text { Total, dry and wet atmospheric deposition of } \mathrm{N} \text { and } \mathrm{P} \text { is taken from Barendregt et al. } \\
\text { (1995), Van Beek et al. (2004a), Buijsman (2004), Fraters et al. (2004, 2007) and } \\
\text { personal communication of Maarten Ouboter. Estimated concentrations differ } \\
\text { markedly among sites and studies }\end{array}$ \\
\hline $\begin{array}{l}\text { Upward, inward } \\
\text { seepage }\end{array}$ & $\begin{array}{l}\text { N: } 0-8 \\
\text { P: } 0-3\end{array}$ & Concentrations from water board estimates or Van Drecht et al. (1996) \\
\hline Inlet surface water & $\begin{array}{l}\text { N: } 0-14 \\
\text { P: } 0-31\end{array}$ & $\begin{array}{l}\text { From water board or national monitoring data. Generally derived from time series of a } \\
\text { nearby water quality monitoring station in the relevant water body. Median } \\
\text { concentration used for the period during the year when water is pumped in, generally } \\
\text { summer }\end{array}$ \\
\hline Agricultural inputs & $\begin{array}{l}\text { N: } 0-384 \\
\text { P: } 0-35\end{array}$ & $\begin{array}{l}\text { Extrapolated from Van Beek et al. (2004a, 2007) to specific land use characteristics and } \\
\text { fertilizer practice of a polder, where possible. Involves animal manure (droppings on } \\
\text { the field), stable slurry (mixture of dung and urine collected in the stable and sprayed } \\
\text { over the field) and artificial fertilizer. Artificial fertilisation rates were also obtained } \\
\text { separately from the official records in CBS (2000b) }\end{array}$ \\
\hline $\begin{array}{l}\text { Internal mineralisation } \\
\text { of peat soil }\end{array}$ & $\begin{array}{l}\text { N: } 0-244 \\
\text { P: } 1-10\end{array}$ & $\begin{array}{l}\text { Aerobic peat mineralises. Maintaining a ditch water level below the soil surface leads to } \\
\text { mineralisation, which generates nutrients readily available for assimilation. Estimates } \\
\text { of Schothorst (1977) and Van Beek et al. (2004a, 2007) were adjusted for each polder } \\
\text { depending on ditch water level. }\end{array}$ \\
\hline $\begin{array}{l}\text { Slush application on } \\
\text { banks }\end{array}$ & $\begin{array}{l}\text { N: } 0-14 \\
\text { P: } 0-40\end{array}$ & $\begin{array}{l}\text { Ditch maintenance involves annual removal of aquatic vegetation and dredging of ditch } \\
\text { sediment once every 3-10 years. This sediment is a soft watery mud, which is } \\
\text { deposited on the bank or sprayed far into the field. Van Beek et al. (2004a) offers an } \\
\text { experimentally verified estimate, which has been adjusted to the area of ditches in a } \\
\text { polder }\end{array}$ \\
\hline $\begin{array}{l}\text { Sewage works effluents, } \\
\text { storm overflows }\end{array}$ & $\begin{array}{l}\mathrm{N}: 0-1 \\
\mathrm{P}: \sim 0\end{array}$ & $\begin{array}{l}\text { From budget of the water board. Only present in the Overwaard and Nederwaard of the } \\
\text { Ablasserwaard. See Table } 1\end{array}$ \\
\hline Nitrogen fixation & N: $0-18$ & $\begin{array}{l}\text { Alder carr has symbiotic Acinetobacter known to fix atmosperic nitrogen. We applied an } \\
\left.\text { area-specific estimate from Barendregt et al. (1995; } 70 \mathrm{~kg} \mathrm{~N} \mathrm{ha}^{-1} \mathrm{y}^{-1}\right) \text { and multiplied } \\
\text { this with the area under alder carr }\end{array}$ \\
\hline \multicolumn{3}{|l|}{ Outputs } \\
\hline $\begin{array}{l}\text { Evapotranspiration, } \\
\text { volatilisation }\end{array}$ & $\mathrm{N}: 0-7$ & $\begin{array}{l}\text { Evapotranspiration of water is no loss of } \mathrm{N} \text { or P. We included a term for volatilisation } \\
\text { of } \mathrm{N} \text { during manure application based on Van Beek et al. (2007) }\end{array}$ \\
\hline $\begin{array}{l}\text { Downward, outward } \\
\text { seepage }\end{array}$ & $\begin{array}{l}\text { N: } 0-18 \\
\text { P: } 0-4\end{array}$ & See upward seepage \\
\hline Outlet surface water & $\begin{array}{l}\text { N: } 5-33 \\
\text { P: } 0-28\end{array}$ & See inlet surface water \\
\hline Agricultural outputs & $\begin{array}{l}\text { N: } 56-381 \\
\text { P: } 0-39\end{array}$ & $\begin{array}{l}\text { Van Beek et al. (2003) offer estimates for output of agricultural products from the polder } \\
\text { parcel (hay, milk, meat), these were adjusted to the separate polders }\end{array}$ \\
\hline Denitrification & N: $15-213$ & $\begin{array}{l}\text { Denitrification from peat wetlands has been measured and reviewed by Van Beek et al. } \\
\text { (2004b). Comparable assessments from river floodplain wetlands (Olde-Venterink } \\
\text { et al. 2006) have been used for verification }\end{array}$ \\
\hline $\begin{array}{l}\text { Difference between } \\
\text { total inputs and } \\
\text { outputs }\end{array}$ & $\begin{array}{l}\mathrm{N}:-18 \text { to }+8 \% \\
\mathrm{P}:-91 \text { to }+24 \%\end{array}$ & $\begin{array}{l}\text { Annual net storage or loss is not presented as a separate term. Net storage can be } \\
\text { reflected in an increase in N or P content of the soil. See text }\end{array}$ \\
\hline
\end{tabular}

All are estimated in $10^{3} \mathrm{~kg} \mathrm{~N}$ or $\mathrm{P}_{\text {polder }}{ }^{-1} \mathrm{y}^{-1}$ and reported as $\mathrm{kg} \mathrm{ha}^{-1} \mathrm{y}^{-1}$

This mean surplus is significantly different from zero ( $t$-test, $p=0.01)$. The direct inputs and outputs due to agriculture dominate both budgets of $\mathrm{N}$ and $\mathrm{P}$
(Fig. 2). Agriculture directly accounts for over $60 \%$ of the nutrient inputs into a polder, and it is responsible for $90 \%$ of the $\mathrm{N}$ removal, and $80 \%$ of 


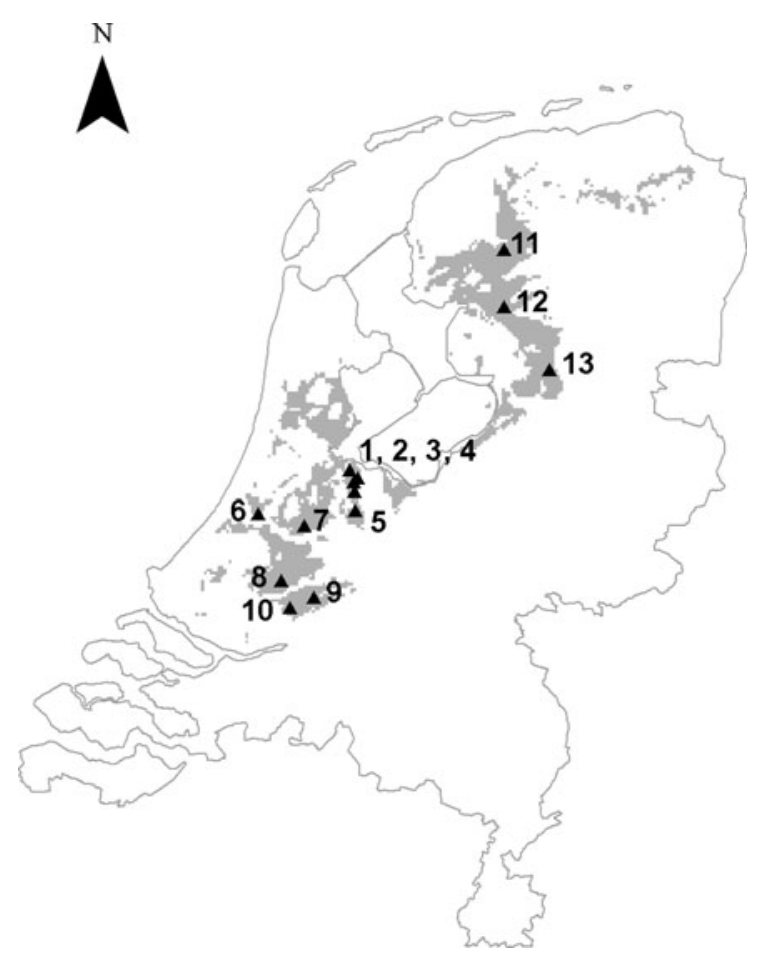

Fig. 1 Location of the thirteen polders in the low-lying peat districts of The Netherlands. Land with peat soils is hatched (adopted from Rienks et al. 2002, p. 26). Numbers correspond with those given in Appendix

the $\mathrm{P}$ removal as export of hay, dairy and meat products (cf. Table 2). The two other substantial items on the input side are mineralisation of the peat soil and atmospheric nitrogen deposition. Most remarkably the items on the water balance provide only minor contributions to the nutrient fluxes, less than $30 \mathrm{~kg} \mathrm{~N} h a^{-1} \mathrm{y}^{-1}$ and $2 \mathrm{~kg} \mathrm{Pha}^{-} \mathrm{y}^{-1}$. The only major quantitative difference between the $\mathrm{N}$ and $\mathrm{P}$ budgets is the substantial role of denitrification in the former and a larger proportion of sedimentary $\mathrm{P}$ dredged as slush from the ditches and deposited on the banks (Fig. 2), otherwise the distribution over different budget items is comparable.

Variability among polders was assessed in a principal components analysis bringing together all quantified variables (Fig. 3; Table 4). In Fig. 3, the correlation patterns of the different variables are grouped into two panels only for accessibility, they were entered simultaneously in one single PCA. The three-first principal components together accounted for $63 \%$ of the total variability, and several clusters of closely co-varying variables are apparent (Fig. 3). The first principal component (PC1, 33\% of variance) reflects a major land-use gradient with the proportion of the polder under agriculture and open water as two opposite ends (see also Fig. 4a). The fraction of open water in ditches (Fig. 3) closely covaried with agriculture, so the negative correlation between open water and agriculture is due to ponds and lakes, not ditches. Also, polder level and water level in ditches covaried with PC1, but the correlations were less than 0.55 (Table 4), and the relation of polder level and percentage agriculture was not linear: polders with little agriculture were all comparatively high $(\geq 1 \mathrm{~m}$ NAP), whereas agricultural polders occurred at all elevations (Fig. 4b). Another nonlinear pattern is apparent for downward seepage (Fig. 4b): it is low for the deepest polders with little open water, but maximal in polders combining an intermediate fraction of open water and a relatively high position in the surrounding landscape. Water budget items also covaried with the first PC: more water is pumped into polders with less agriculture, and these also have higher water losses through downward seepage and evapotranspiration. The majority of the Nitrogen budget items were found to covary positively with PC1: they clustered in the right half of the plot (Fig. 3 lower panel, Fig. 4e, h).

The second principal component (PC2, 22\% of variance) probably reflects a large scale urbanisation gradient depicted by the opposing variables population density (at municipality level) and total polder area. Polders as separately managed units appear to be larger where population density is lower. Precipitation was found to covary significantly with this PC2, possibly in part because urbanisation happens to covary with variability in long-term mean rainfall across the low peatlands in the Netherlands (Heijboer and Nellestijn 2002), but also because the highest precipitation was observed in the small Vlietpolder, with a high population density in adjacent municipalities. The third principal component (PC3, 11\%) still explains a significant proportion of the total variance (Table 4). Shoreline density, N-flux from peat mineralisation and $\mathrm{N}$-fertilizer use at municipality scale correlated negatively and upward seepage correlated positively with this PC.

The small input-output differences of the $\mathrm{N}$ balance were found to relate to the volume of water pumped out of a polder after stepwise regressions 
Fig. 2 Mean water, nitrogen en phosphorus balances of the thirteen peat polders studied. Balance terms are explained in Tables 1, 2 and 4. Minor budget entries have been left out from the legend for readability
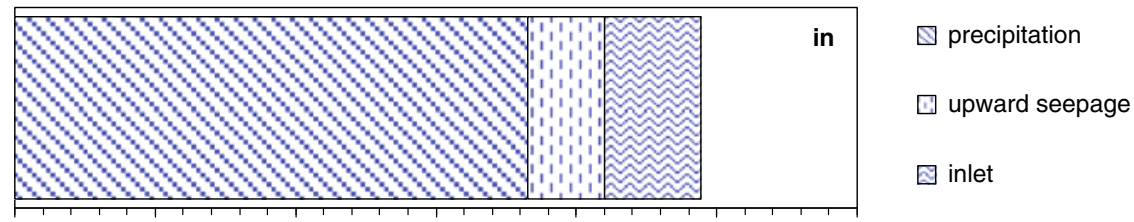

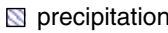

apward seepage

Q

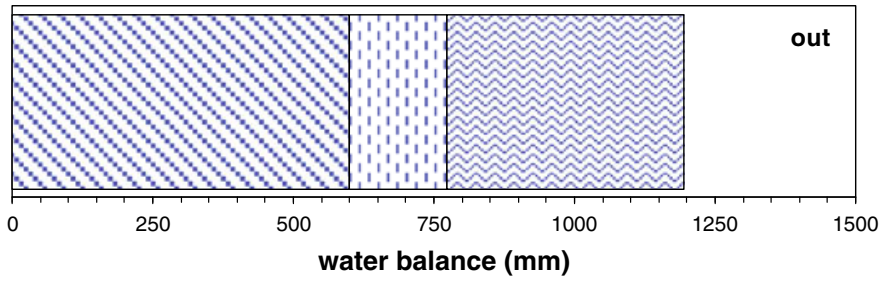

evapotranspiration

downward seepage

จ outlet

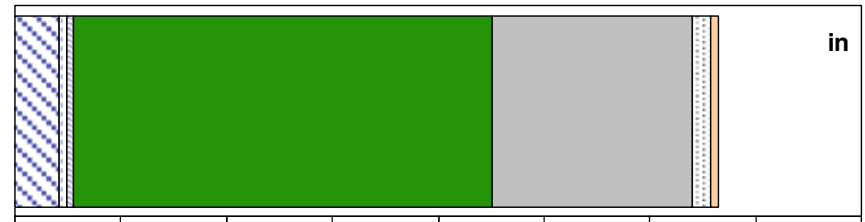

atmosphere

agriculture

mineralisation

slush deposition

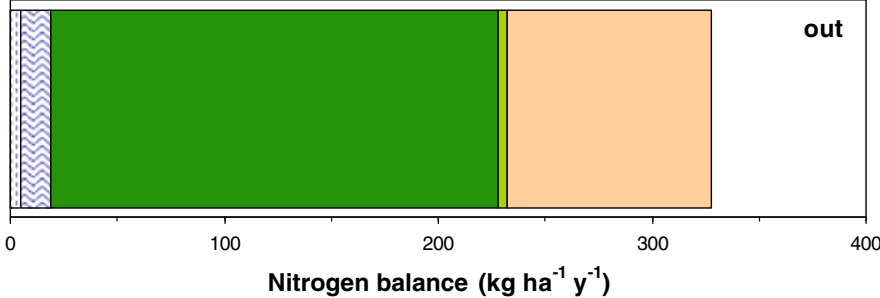

outlet

agriculture

$\square$ denitrification
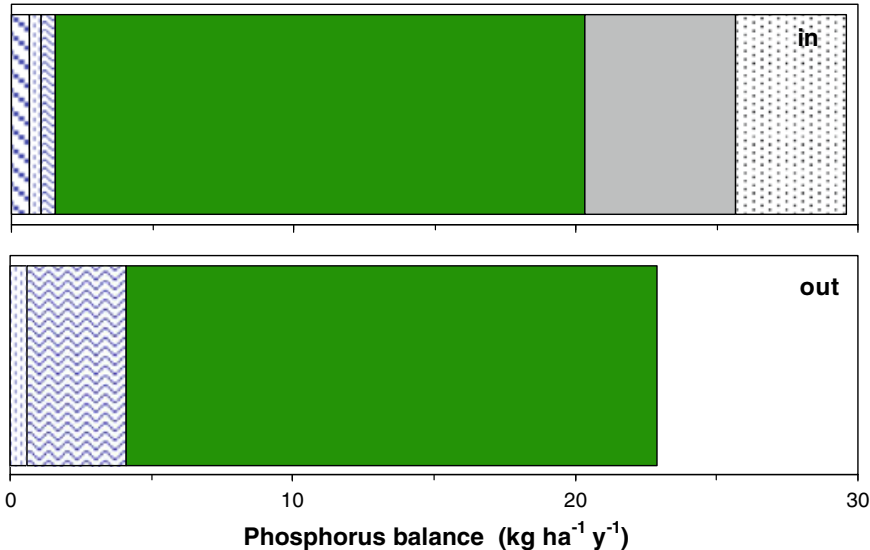

selecting from 15 variables of land use, landscape pattern and water balance (Table 5). Overall, the differences of the P-budgets were proportionally much larger than those of the N-budgets. These P-differences related to several variables, and the proportion of land under agriculture was the most important (Table 5), confirming the patterns of the
PCA. The most conspicuous P deficits were found in polders with a large proportion of land under nature protection, where hay-making is the important export term. The nitrogen differences, in contrast, were not necessarily negative in nature reserves, due to the almost constant blanket of atmospheric deposition (Fig. 4d). 
Table 3 Land use, demographic and administrative data sources

\begin{tabular}{|c|c|c|}
\hline Variables used & Resolution & Data source \\
\hline $\begin{array}{l}\text { Elevation, median polder land level relative to Dutch Ordnance } \\
\text { (NAP, m); ditch water level; dry board (difference land level } \\
\text { and ditch water level) }\end{array}$ & Polder & $\begin{array}{l}\text { Water board reports, topographic map, digital } \\
\text { elevation data (as compiled in Vernooij and } \\
\text { Vermaat (2009). }\end{array}$ \\
\hline $\begin{array}{l}\text { Percentage of agricultural land, forested land, open water, } \\
\text { residential built-up land, road cover }\end{array}$ & Polder & CBS (2000b) \\
\hline $\begin{array}{l}\text { Density of shorelines of ditches and larger open water bodies } \\
\left(\mathrm{km} \mathrm{km}^{-2}\right) \text {; area of these two categories; orientation of ditches } \\
(\text { since fx NE is the same direction as SW, these are pooled } \\
\left.\text { to } 0-180^{\circ} \text {, from } \mathrm{N}\right)\end{array}$ & Polder & $\begin{array}{l}\text { Top10vector, digital topographic map of The } \\
\text { Netherlands at 1:10,000 (Kadaster 2007) }\end{array}$ \\
\hline Nitrogen fertilizer use in 2002; population density in 2000 & Municipality & CBS (2000a, b); www.cbs.nl \\
\hline
\end{tabular}

Although the polders differed substantially in ditch density and ditch orientation $\left(19-40 \mathrm{~km} \mathrm{~km}^{-2}\right.$ and $82-127^{\circ}$ ), these landscape indicators were not related distinctly to any of the nutrient budget terms. Ditch orientation did covary with the second PC, implying that larger polders had a larger proportion of the ditches oriented SE-NW.

\section{Discussion}

Agricultural nutrient inputs and outputs were found to dominate the nutrient budgets (Fig. 2), and these generally covaried straightforwardly with the areal coverage by agriculture in a polder (Fig. 3). Strictly seen, agricultural nitrogen outputs were somewhat higher than agricultural inputs, whereas agricultural phosphorus inputs and outputs were similar (although the overall balance had a surplus, Fig. 2, see below and Schothorst 1977). Polders without agriculture still received substantial inputs of $\mathrm{N}$ and $\mathrm{P}$ (Fig. $4 \mathrm{~g}$ ), i.e. from atmospheric deposition $(\mathrm{N})$, mineralisation of the peat soil, and reworking of ditch sediments. Though not of prime importance, these inputs were not negligible in agricultural polders either. Next to agricultural fluxes, nitrogen was exported out of the polders mainly by denitrification and phosphorus left the polders with surface water. In this way, the studied peat polders are a net source of phosphorus to the receiving water system. Without denitrification, the N-budgets would display major surpluses (Fig. 2). Estimated denitrification rates were probably highest in the deeper polders under agriculture (Fig. 4), where ditch and groundwater tables are shallow combining extensive anoxic transition zones and an ample supply of nitrate (cf Koerselman et al. 1993; Best and Jacobs 2001; Van Beek et al. 2004b; Olde Venterink et al. 2006).

Agricultural land use also affected water balance terms (Fig. 3): polders with more open water and less agriculture had higher evapotranspiration and downward seepage, here also more water was pumped in. In these polders the maintenance of a certain high water level is often a major target for water management. Polders with more agriculture also had higher volumes of water pumped out (Fig. 4h), which is consistent with the need for drainage coupled to agricultural practice.

Most polders had annual phosphorus balances with a surplus, with the exception of three polders which contain a large nature reserve. The surpluses suggest net $\mathrm{P}$-accumulation, probably the peat soil is enriched with $\mathrm{P}$ under agricultural practice. Beltman et al. (2009) report elevated total $P$, iron-bound $P$ as well as readily available (Olsen- or acetate-lactate extracted) $\mathrm{P}$ in Dutch peatlands under intensive dairy farming. Drainage causes mineralisation (Schothorst 1977), which makes nutrients potentially available but oxidises iron, which would bind $\mathrm{P}$ (Bridgham et al. 2001; Zak et al. 2004). Probably, the soil matrix and interstitial water of these peatlands witness dynamic sorption and resorption fluxes (e.g. Fraters et al. 2007). Apparently the soil is the major site of nutrient retention in these peat polders, also since dredging of sludge redistributes the nutrients that are being stored in ditch sediments onto the land. Our aggregation at polder level precluded an analysis of spatial and temporal variability in water level across a polder or 
Fig. 3 Correlation coefficients of variables of land use, landscape pattern, water (upper panel) and nutrient balances (bottom panel, N: filled symbols, $\mathrm{P}$ : open symbols) with the first two principal components (see also Table 4). The shaded square indicates the area where correlations are $<0.55$, hence have a probability over 0.05 and are considered not significant
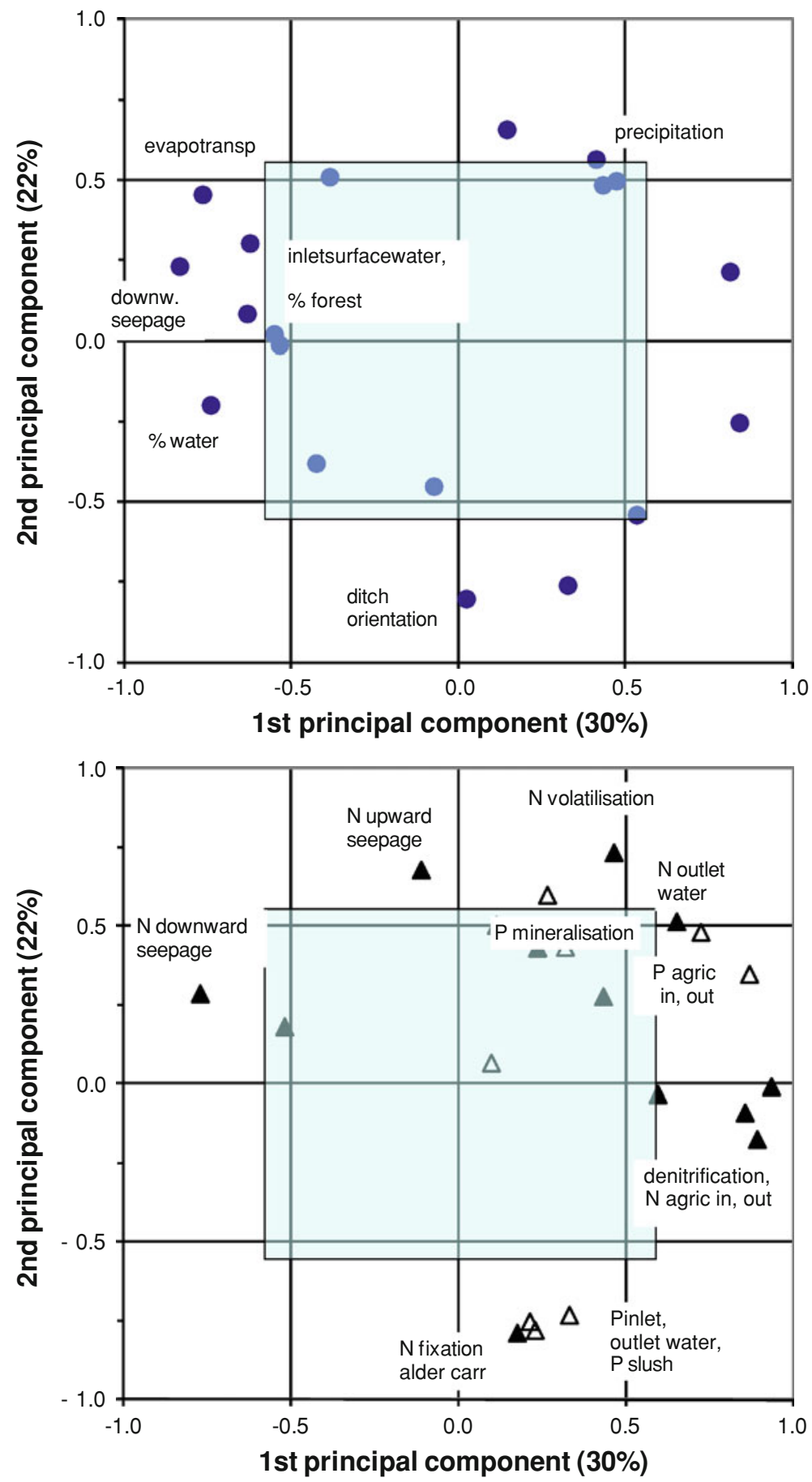
Table 4 Correlation of land use, water balance and nutrient balance variables ${ }^{\mathrm{a}}$ in thirteen peat polders with the first three components of a principal component analysis (83\% explained variance)

\begin{tabular}{|c|c|c|c|}
\hline Principal component ${ }^{\mathrm{b}}$ (percent of variance explained) & PC1 $(30 \%)$ & PC2 (22\%) & PC3 $(11 \%)$ \\
\hline \multicolumn{4}{|l|}{ Land use and landscape pattern variables } \\
\hline Total area & 0.33 & -0.76 & -0.08 \\
\hline Percent water & -0.74 & -0.20 & 0.13 \\
\hline Polder level & -0.55 & -0.02 & -0.49 \\
\hline Percent agriculture & 0.82 & 0.21 & 0.39 \\
\hline Percent forest & -0.63 & 0.08 & 0.32 \\
\hline Percent covered by roads & 0.54 & -0.49 & -0.25 \\
\hline Fraction of surface water in ditches & 0.84 & -0.26 & 0.39 \\
\hline Ditch orientation & 0.03 & -0.80 & -0.13 \\
\hline Shoreline density & -0.42 & -0.38 & -0.59 \\
\hline Human population density at municipality scale & 0.15 & 0.65 & -0.30 \\
\hline $\mathrm{N}$-fertiliser use from municipality-scale statistics & -0.53 & -0.01 & -0.62 \\
\hline \multicolumn{4}{|l|}{ Water balance } \\
\hline Precipitation & 0.42 & 0.56 & -0.11 \\
\hline Upward seepage & -0.38 & 0.51 & 0.66 \\
\hline Inlet surface water & -0.62 & 0.30 & 0.20 \\
\hline Evapotranspiration & -0.76 & 0.46 & 0.18 \\
\hline Downward seepage & -0.83 & 0.23 & 0.14 \\
\hline \multicolumn{4}{|l|}{ Nitrogen balance } \\
\hline $\mathrm{N}$ in upward seepage & -0.11 & 0.68 & -0.43 \\
\hline $\mathrm{N}$ inlet water & -0.52 & 0.18 & 0.15 \\
\hline $\mathrm{N}$ inputs from agriculture & 0.90 & -0.18 & -0.04 \\
\hline $\mathrm{N}$ from peat mineralisation & 0.44 & 0.27 & 0.67 \\
\hline $\mathrm{N}$ from ditch sediment dredging & 0.60 & 0.04 & 0.27 \\
\hline $\mathrm{N}$-fixation by alder symbionts & 0.18 & -0.79 & -0.26 \\
\hline $\mathrm{N}$ volatilisation & 0.46 & 0.73 & -0.09 \\
\hline $\mathrm{N}$ downward seepage & -0.77 & 0.28 & 0.03 \\
\hline $\mathrm{N}$ outlet water & 0.65 & 0.51 & 0.31 \\
\hline $\mathrm{N}$ outputs from agriculture & 0.94 & -0.01 & -0.16 \\
\hline $\mathrm{N}$ denitrification in soil and sediments & 0.86 & -0.09 & -0.29 \\
\hline \multicolumn{4}{|l|}{ Phosphorus balance } \\
\hline $\mathrm{P}$ inlet water & 0.22 & -0.75 & 0.26 \\
\hline $\mathrm{P}$ inputs from agriculture & 0.87 & 0.35 & 0.00 \\
\hline $\mathrm{P}$ from peat mineralisation & 0.27 & 0.60 & -0.44 \\
\hline $\mathrm{P}$ from ditch sediment dredging & 0.23 & -0.78 & 0.25 \\
\hline P downward seepage & 0.10 & 0.07 & -0.55 \\
\hline P outlet water & 0.33 & -0.73 & 0.18 \\
\hline $\mathrm{P}$ outputs from agriculture & 0.73 & 0.48 & 0.27 \\
\hline
\end{tabular}

A fourth principal component explained another $9 \%$. Correlations over 0.55 are considered significant at $p=0.05$ (italicized here) and those over 0.68 at $p=0.01$ (italicized and bold). Variables with correlations less than 0.55 to any of these three principal components are omitted

${ }^{a}$ Omitted variables: water level in ditch, dry board, outlet surface water, percent built-up P-fertilizer application from municipality-scale statistics, $\mathrm{N}$ and $\mathrm{P}$ in atmospheric deposition, $\mathrm{N}$ in outlet water, $\mathrm{P}$ in inlet water, $\mathrm{P}$ in atmospheric deposition

${ }^{b}$ The first component is interpreted as a complex of factors related to the proportion of the polder that is under agriculture versus the proportion of surface water, the second to total polder area versus human population density in the municipalities that cover the polder, and the third to a less equivocal complex of water edge density, reported $\mathrm{N}$-fertilizer statistics at municipality scale, $\mathrm{P}$ in downward seepage 
Fig. 4 Scatter plots of selected pairs of variables, based on the covariance in the PCA (cf. Fig. 3 and outcomes of the stepwise regressions of variables related to nutrient retention (from Table 5): a the fraction of the total polderarea covered with water (filled symbols) and built-up land (open symbols) versus the fraction of agricultural land; $\mathbf{b}$ mean polder elevation relative to sea level (filled symbols) and downward seepage (open symbols) versus the fraction of open water; $\mathbf{c}$ the difference in the annual $\mathrm{P}$ balance versus the fraction of land under agriculture; $\mathbf{d}$ difference in the annual $\mathrm{N}$ balance versus the fraction of land under agriculture) denitrification versus polder level; e denitrification versus polder land level; $\mathbf{f}$ ditch water level versus polder land level; g total and agricultural $\mathrm{N}$ inputs as a function of the percentage agriculture; and $\mathbf{h}$ the quantity of water let out annually as a function of percentage agriculture
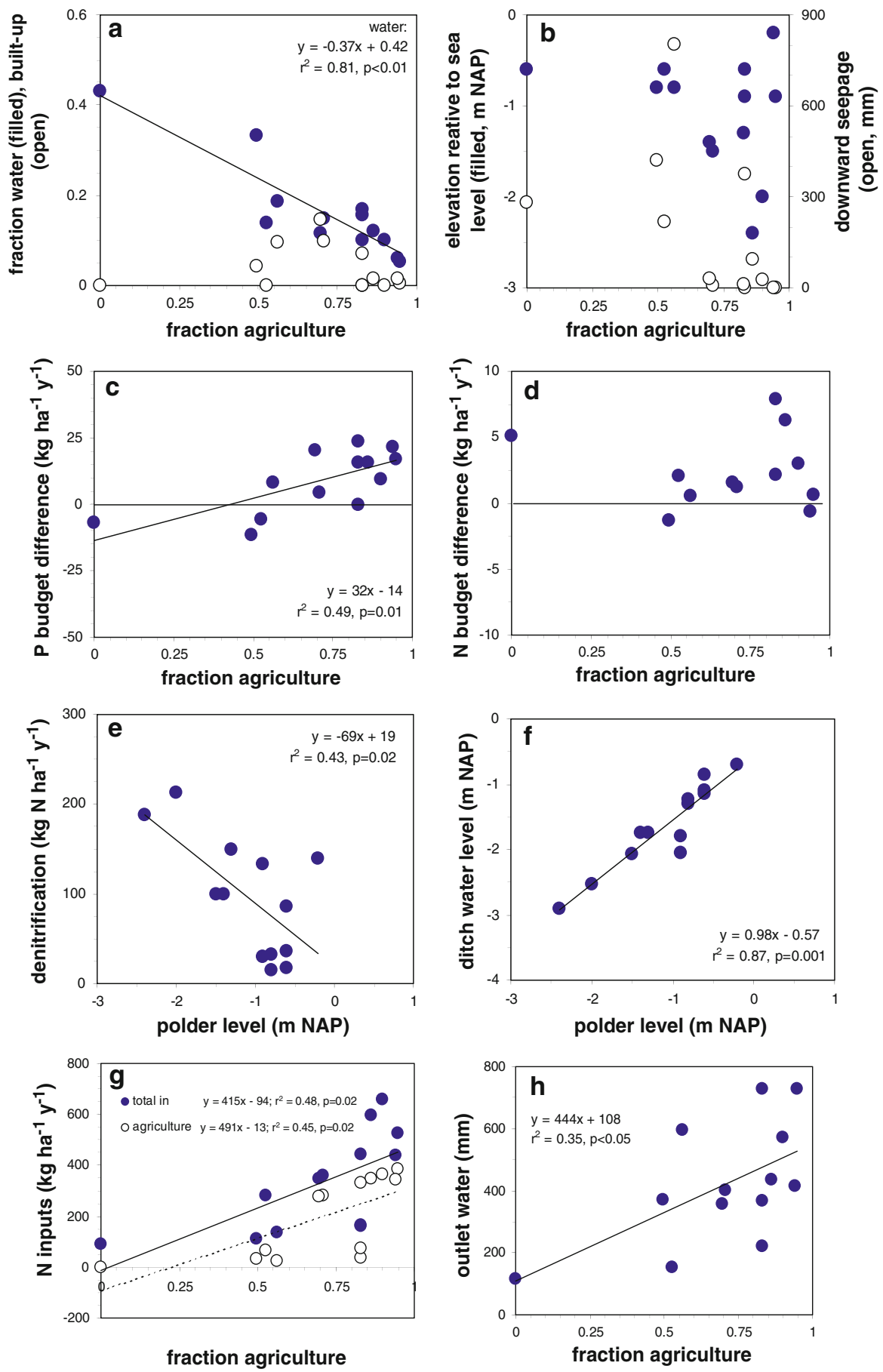

field (cf Meuleman et al. 2004; Van Beek et al. 2004b; Dekker et al. 2005). Hence ditch water level closely tracked the level of the land, and did not add explanatory power to our analysis.
Intensification of agricultural practice commenced in these polders after the second World War with reallotment and drainage schemes as well as mechanisation, increased fertilisation rates and cattle stocking 
Table 5 Stepwise forward multiple regressions of a range of dependent variables reflecting retention processes with independent variables of land use, landscape pattern and the water balance

\begin{tabular}{|c|c|c|c|c|c|}
\hline Dependent & Step & Selected independent variable & $r^{2}$ & $p$ & Slope \\
\hline $\mathrm{N}$ budget difference & 1 & Outlet surface water & 0.35 & 0.035 & -0.019 \\
\hline \multirow[t]{5}{*}{$\mathrm{P}$ budget difference } & 1 & Percent agriculture & 0.82 & 0.001 & 137.41 \\
\hline & 2 & Fraction water in ditch & 0.90 & 0.001 & -72.66 \\
\hline & 3 & Percent built-up & 0.97 & 0.001 & 170.47 \\
\hline & 4 & Polder land level & 0.99 & 0.010 & 6.40 \\
\hline & 5 & Percent water & 0.99 & 0.047 & -54.48 \\
\hline Denitrification & 1 & Evapotranspiration & 0.47 & 0.009 & -0.71 \\
\hline $\mathrm{N}$ from ditch sediment dredging & 1 & Fraction of surface water in ditches & 0.53 & 0.050 & 18.14 \\
\hline $\mathrm{P}$ from ditch sediment dredging & 1 & Total polder area & 0.35 & 0.034 & -0.88 \\
\hline \multirow[t]{2}{*}{$\mathrm{N}$ outputs from agriculture } & 1 & Fraction of surface water in ditches & 0.61 & 0.001 & 359.03 \\
\hline & 2 & Polder land level & 0.78 & 0.002 & -77.00 \\
\hline $\mathrm{P}$ outputs from agriculture & 1 & Percentage water & 0.38 & 0.025 & -69.29 \\
\hline
\end{tabular}

List of independent variables entered to select from: total area, percent water, polder level, dry board, percent agriculture, percent built-up, percent covered by roads, fraction of surface water in ditches, shoreline density, human population density, fertiliser application from municipality-scale statistics, upward seepage, inlet surface water, evapotranspiration, downward seepage, outlet surface water. Presented are the explained variance $\left(r^{2}\right)$ and level of significance of each added independent variable, and the slope

densities (Harms et al. 1987; Best and Jacobs 2001). If fertilisation during these past 50 years would have been responsible for a continuous surplus on the nutrient balance, then this should be reflected in the nutrient content of the top soil (cf Reddy et al. 1993). Indeed, Beltman et al. (2009) report elevated P-contents for agricultural land. Unfertilized peatland in a nature reserve and deeper soils $(<60 \mathrm{~cm})$ had a $P$ content of $600-800 \mathrm{~kg} \mathrm{ha}^{-1}$, whereas the upper $50 \mathrm{~cm}$ soil of agricultural land contained about $1400 \mathrm{~kg} \mathrm{ha}^{-1}$. A mean surplus of $15 \mathrm{~kg} \mathrm{ha}^{-1} \mathrm{y}^{-1}$ (Fig. 4c, for 10 polders with substantial agricultural coverage) would need 47 years to accumulate such a high $\mathrm{P}$ content, an estimate that is remarkably close to the real time passed since the onset of agricultural intensification, given the uncertainties in our estimate and the differences in land use history among these 10 agricultural polders. Together, this adds credibility to the balances we have constructed and it suggests that farming practice and water management may have led to an approximate steady state in nutrient fluxes over the past decades.

Principal mechanisms contributing to nutrient retention in these peat polders were firstly accumulation in the peat soil [supportive soil data in Fraters et al. (2007) and Beltman et al. (2009)] and ditch sediments, and secondly denitrification, though the latter is strictly speaking not retention but a loss to the atmosphere. Retention is taken here as any process preventing loading with nutrients of the surface water. Accumulation in ditch sediments is only a temporary sink, since dredging is carried out frequently, and the retained nutrients are recycled on land. Also the $\mathrm{N}$ and $\mathrm{P}$ accumulating in the upper peat soil are probably subject to substantial turn-over, since the peat mineralises continuously as well. Still, the observed matching between our annual surplus and accumulated $\mathrm{P}$ content of the soil, does suggest a net retention in the soil. Our multivariate analyses do not suggest that the spatial distribution of ditches in these polders contributes distinctly to nutrient retention. Water edge, our prime indicator of landscape pattern, varied only with a factor 2 among the polders (19-40 $\mathrm{km} \mathrm{km}^{-2}$ ), whereas the proportion of surface water varied between 5 and $43 \%$ and covaried inversely with the proportion of land under agriculture. Retention in these aquatic sediments is probably considerable, as witnessed from the nutrient fluxes that are brought back to the land by dredging $\left(9 \mathrm{~kg} \mathrm{~N} \mathrm{ha}^{-1} \mathrm{y}^{-1}\right.$ or $3 \%$ of inputs and $4 \mathrm{~kg} \mathrm{P}$ $\mathrm{ha}^{-1} \mathrm{y}^{-1}$ or $13 \%$ ).

In short, bulk retention in these peat polders appears rather governed by the peat soil and ditch sediment, than by the quantity of littoral edge present. 
Whereas agricultural inputs and outputs dominate the budgets, a termination of agricultural practice would still lead to substantial nutrient fluxes: total inputs would remain at $\sim 40 \%$ of the present (Fig. 2) if the present water management was maintained, since this involves continued mineralisation and ditch sludge dredging. A limited raising of the water table can even enhance mineralisation (Van Dijk et al. 2004).

\section{Conclusions}

1. Nutrient budgets in 13 peat polders in the lower part of the Netherlands were found to be dominated by agricultural fluxes. Water balance terms contributed only little.

2. Nitrogen budgets were found to be in balance, with denitrification the second important output next to agriculture, and peat mineralisation the second important input.

3. Phosphorus budgets suggest a net annual surplus, which is in agreement with the know history of fertilization since $\sim 1950$ and accumulated topsoil P-content observed in agricultural versus pristine peatlands. Next to agriculture, the major output is with drainage water, pumped to adjacent receiving waters. Polders with a substantial proportion under agriculture had $\mathrm{P}$ budget surpluses.

4. Covariance in landscape pattern, land use intensity, water and nutrient budgets was assessed in a principal components analysis. Three major components explained $63 \%$ of the variance. The first was clearly related to the proportion of a polder under agriculture, and it covaried with variability in most nitrogen budget items. The second was related to an urbanisation gradient, and $\mathrm{P}$ in surface water covaried with this component: higher loads in areas with less urbanisation. Thus variability in nutrient budgets among polders is largely governed by intensity of agricultural land use.

5. Retention could not be related to independent variability in landscape pattern, such as the density of littoral zones as water edge or area of surface water in a polder. Rather, the peat soil itself probably operated as the main location: $\mathrm{P}$ is sorbed to $\mathrm{Fe}$ and organic matter, and $\mathrm{N}$ is denitrified. Water area correlated negatively with the proportion of land under agriculture.

Acknowledgements The work presented here was funded by the program 'Climate changes spatial planning' as BSIK-KvR ME5. The data were compiled from numerous reports and databases made generously available by the water boards Waternet, Stichtse Rijnlanden, Rijnland, Rivierenland, Wetterskip Fryslan, Schieland en de Krimpenerwaard and Groot Salland. The following colleagues contributed with data and discussion: Christy van Beek, Wim Twisk, Ronald Gylstra, Hella Pomarius, Thijs ten Bras, Maarten Ouboter, Jaap Hofstra, Henk Hardenveld, Jos van Rooden, Theo Claassen and Wim Wiegman. Marjan van Herwijnen critically evaluated the layout of the balance spreadsheet. Dico Fraters is thanked for the discussion on $\mathrm{N}$ and $\mathrm{P}$ in precipitation. Andre Dias, Bart Hoorens and Rien Aerts are thanked for discussions and a cooperative working spirit in the project ME5.

Open Access This article is distributed under the terms of the Creative Commons Attribution Noncommercial License which permits any noncommercial use, distribution, and reproduction in any medium, provided the original author(s) and source are credited.

\section{Appendix}




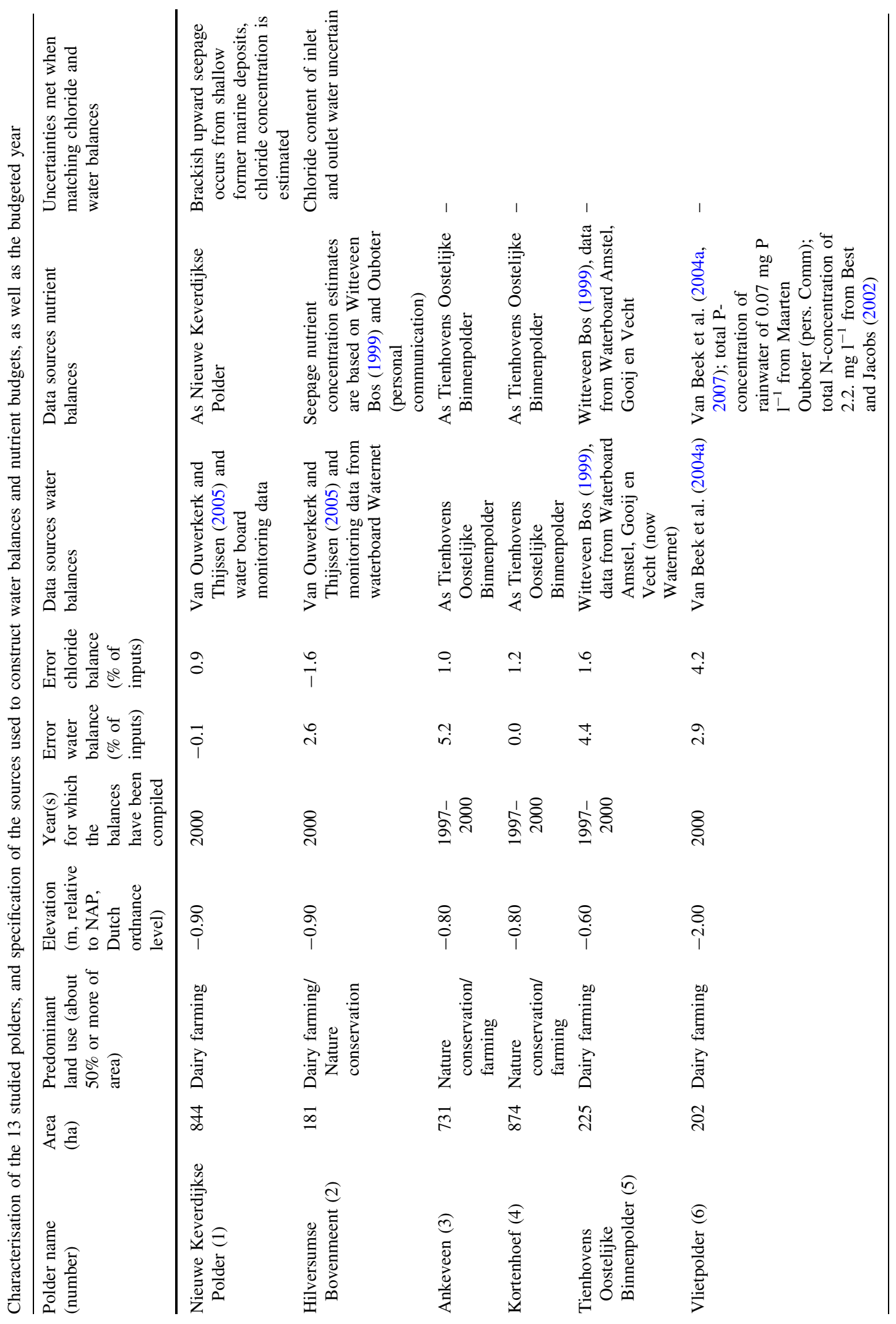




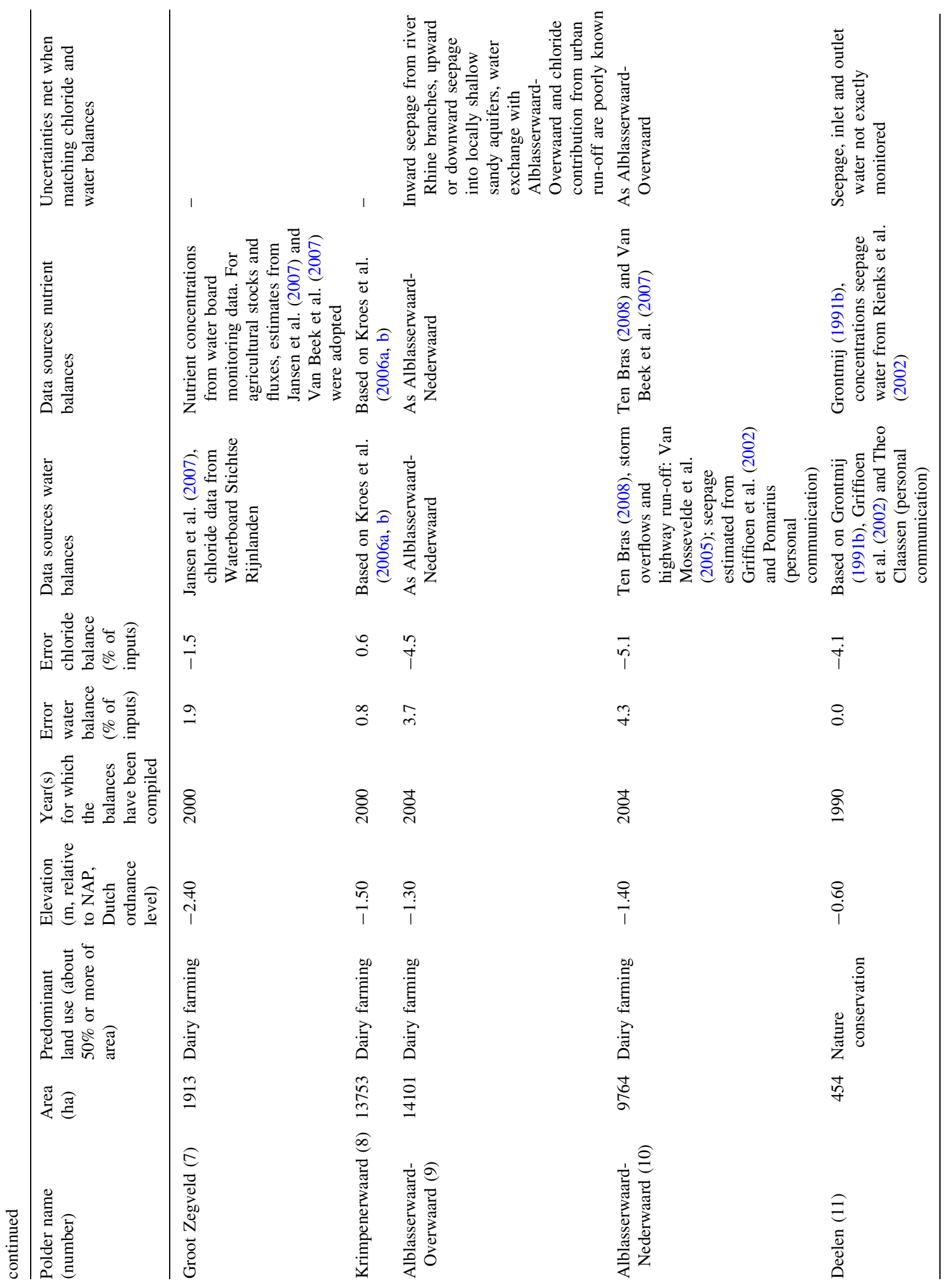




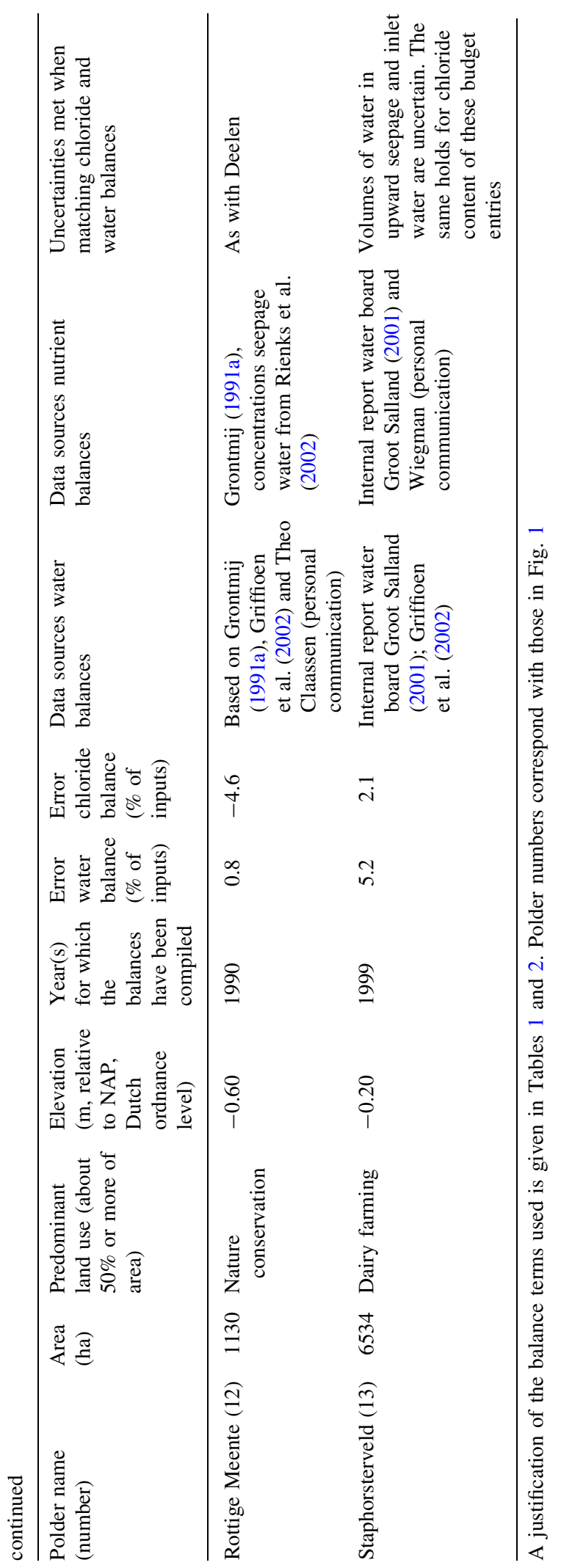




\section{References}

Aerts R (2000) Possibilities for carbon storage in grasslands on peat in the Netherlands. In: Van Amstel A (ed) Monitoring $\mathrm{CO}_{2}$ sinks in the Netherlands. Priorities for improvement. Wageningen University, Wageningen, pp 25-27

Bakker SA, Van den Berg NJ, Speleers BP (1994) Vegetation transitions of floating wetlands in a complex of turbaries between 1937 and 1989 as determined from aerial photographs with GIS. Vegetatio 114:161-167

Balmford A, Bruner A, Cooper P, Costanza R, Farber S, Green RE, Jenkins M, Jefferiss P, Jessamy V, Madden J, Munro K, Myers N, Naeem S, Paavola J, Rayment M, Rosendo S, Roughgarden J, Trumper K, Turner RK (2002) Ecologyeconomic reasons for conserving wild nature. Science 297:950-953

Barendregt A, Wassen MJ, Schot PP (1995) Hydrological systems beyond a nature reserve, the major problem in wetland conservation of Naardermeer (The Netherlands). Biol Conserv 72:393-405

Barnard R, Leadley PW, Hungate BA (2005) Global change, nitrification, and denitrification: a review. Global Biogeochem Cycles 19:GB1007

Beltman BGHJ, Smolders A, Vermaat JE (2009) Nature development on meadows: the role of nutrients (In Dutch). Landschap 26:95-102

Best EPH, Jacobs FHH (2001) Production, nutrient availability, and elemental balances of two meadows affected by different fertilization and water table regimes in The Netherlands. Plant Ecol 55:61-73

Best EPH, Van der Schaaf S, Oomes MJM (1995) Responses of restored grassland ditch vegetation to hydrological changes, 1989-1992. Vegetatio 116:107-122

Blomqvist MM, Vos P, Klinkhamer PGL, Ter Keurs WJ (2003a) Declining plant species richness of grassland ditch banks - a problem of colonisation or extinction? Biol Conserv 109:391-406

Blomqvist MM, Bekker RM, Vos P (2003b) Restoration of ditch bank plant species richness: the potential of the soil seed bank. Appl Veg Sci 6:179-188

Brander L, Vermaat JE, Florax RJGM (2006) The empirics of wetland valuation: a meta-analysis. Environ Resour Econ 33:223-250

Bridgham SD, Johnston CA, Schubauer-Berigan JP, Weishampel P (2001) Phosphorus sorption dynamics in soils and coupling with surface and pore water in riverine wetlands. Soil Sci Soc Am J 65:577-588

Buisman E (2004) Jaaroverzicht luchtkwaliteit 2002. RIVM report 50037004

CBS (2000a) Bevolking der gemeenten van Nederland op 1 januari 2000/Population of the municipalities of the Netherlands on January 1, 2000. Netherlands Statistics Service, Voorburg

CBS (2000b) Bestand bodemgebruik/Netherlands digital land use map. Netherlands Statistics Service, Voorburg

Charlier RH, Chaineux MCP, Morcos S (2005) Panorama of the history of coastal protection. J Coastal Res 21:79-111

Dekker SC, Barendregt A, Bootsma MC, Schot PP (2005) Modelling hydrological management for the restoration of acidified floating fens. Hydrol Proc 19:3973-3984
Fraters B, Hotsma PH, Langenberg VT, Van Leeuwen TC, Mol APA, Olsthoorn CSM, Schotten CGJ, Willems WJ (2004) Agricultural practice and water quality in the Netherlands in the 1992-2002 period. Background information for the third EU Nitrates, Directive Member States report. RIVM report 500003002/2004, Bilthoven

Fraters B, Boumans LJM, Van Leeuwen TC, Reijs JW (2007) De uitspoeling van het stikstofoverschot naar grond- en oppervlaktewater op landbouwbedrijven. RIVM report 680716002/2007, Bilthoven

Griffioen J, De Louw PGB, Boogaard HL, Hendriks RFA (2002) De achtergrondbelasting van het oppervlaktewater met N, P en $\mathrm{Cl}$ en enkele ecohydrologische parameters in westelijk laag Nederland. TNO-NITG report 02-166A, Delft

Grontmij (1991a) De Rottige Meenthe, specifiek ecologisch beheersprogramma. Consultancy report for Province Friesland

Grontmij (1991b) Ecologische beheersprogramma's voor laagveenmoerassen in Friesland-Specifiek programma De Deelen. Consultancy report for Province Friesland

Harms WB, Stortelder AHF, Vos W (1987) Effects of intensification of agriculture on nature and landscape in the Netherlands. In: Wolman MG, Fournier FGA (eds) Land transformations in agriculture, SCOPE. Wiley \& Sons, London, pp 357-379

Heathwaite AL (1990) The effect of drainage on nutrient release from fen peat and its implications for water quality - a laboratory simulation. Water Air Soil Pollut 49:159-173

Hefting M, Beltman B, Karssenberg D, Rebel K, Van Riessen M, Spijker M (2006) Water quality dynamics and hydrology in nitrate loaded riparian zones in the Netherlands. Env Pollut 139:143-156

Heijboer D, Nellestijn J (2002) Klimaatatlas van Nederland. De Normaalperiode 1971-2000. KNMI De Bilt

Herzon I, Helenius J (2008) Agricultural drainage ditches, their biological importance and functioning. Biol Conserv 141:1171-1183

Jansen PC, Querner EP, Kwakernaak C (2007) Effecten van waterpeilstrategieen in veenweidegebieden. Een strategiestudie in het gebied rond Zegveld. Alterra report 1516, Wageningen

Kadaster (2007) Productspecificaties basisregistratie topografie. Apeldoorn, The Netherlands, p 64

Keddy PA (2000) Wetland ecology: principles and conservation. Cambridge University Press

Koerselman W, Vankerkhoven MB, Verhoeven JTA (1993) Release of inorganic N, P and K in peat soils-effect of temperature, water chemistry and water level. Biogeochemistry 20:63-81

Kroes JG, Van der Bolt FJE, Leenders TP, Renaud LV (2006a) Systeemanalyse Krimpenerwaard, monitoring stroomgebieden, fase 1. Alterra report 1273, Wageningen

Kroes JG, Van der Bolt FJE, Leenders TP, Renaud LV (2006b) Systeemanalyse Krimpenerwaard, monitoring stroomgebieden, fase 2. Alterra report 1388, Wageningen

Lamers LPM, Falla SJ, Samborska EJ, Van Dulken IAR, Van Hengstum G, Roelofs JGM (2002) Factors controlling the extent of eutrophication and toxicity in sulfate-polluted freshwater wetlands. Limnol Oceanogr 47:585-593 
Meuleman AFM, Beltman B, Scheffer RA (2004) Water pollution control by aquatic vegetation of treatment wetlands. Wetl Ecol Manag 12:459-471

Nieuwenhuis HS, Schokking F (1997) Land subsidence in drained peat areas of the Province of Friesland, The Netherlands. QuartJ Eng Geol 30:37-48

Nol L, Verburg PH, Heuvelink GBM, Molenaar K (2008) Effect of land cover on nitrous oxide inventory in fen meadows. J Environ Qual 37:1209-1219

Olde Venterink H, Wiegman F, Van der Lee GEM, Vermaat JE (2003) Role of active floodplains for nutrient retention in the river Rhine. J Environ Qual 32:1430-1435

Olde Venterink H, Vermaat JE, Pronk M, Wiegman F, Van der Lee GEM, Van den Hoorn MW, Higler LWG, Verhoeven JTA (2006) Importance of sedimentation and denitrification for plant productivity and nutrient retention in various floodplain wetlands. Appl Veg Sci 9:163-174

Qualls RG, Richardson CJ (1995) Forms of soil phosphorus along a nutrient enrichment gradient in the northern Everglades. Soil Sci 160:183-198

Reddy KR, DeLaune RD, DeBusk WF, Koch MS (1993) Longterm nutrient accumulation rates in the Everglades. Soil Sci Soc Am J 57:1147-1155

Richardson CJ (1985) Mechanisms controlling phosphorus retention capacity in freshwater wetlands. Science 228: 1424-1427

Rienks WA, Gerritsen AL, Meulenkamp WJH (2002) Behoud veenweidegebied, een ruimtelijke verkenning. Alterra report 5633, 118 pp, Alterra Wageningen, The Netherlands

Roden EE, Edmonds JW (1997) Phosphate mobilization in iron-rich anaerobic sediments: microbial Fe(III) oxide reduction versus iron-sulfide formation. Arch Hydrobiol 139:347-378

Salland WaterschapGroot (2001) Invloed huishoudelijke lozingen op waterkwaliteit in Staphorsterveld. Internal Report Water board Groot Salland, Zwolle

Schothorst CJ (1977) Subsidence of low moor peat soils in the western Netherlands. Geoderma 17:265-291

Ten Bras T (2008) Stoffenbalans stroomgebied Alblasserwaard. Internal report Water board Rivierenland, Tiel

Toet S, Van Logtestijn RSP, Schreijer M, Kampf R, Verhoeven JTA (2005) The functioning of a wetland system used for polishing effluent from a sewage treatment plant. Ecol Eng 25:101-124

Twisk W, Noordervliet AW, Ter Keurs WJ (2003) The nature value of the ditch vegetation in peat areas in relation to farm management. Aquati Ecol 37:191-209

Van Beek CL, Brouwer L, Oenema O (2003) The use of farmgate balances and soil surface balances as estimator of nitrogen leaching to surface water. Nutr Cycl Agroecosyst 67:233-244

Van Beek CL, Van den Eertwegh GAPH, Van Schaik FH, Velthof GL, Oenema O (2004a) The contribution of dairy farming on peat soil to $\mathrm{N}$ and $\mathrm{P}$ loading of surface water. Nutr Cycl Agroecosyst 70:85-95

Van Beek CL, Hummelink EWJ, Velthof GL, Oenema O (2004b) Denitrification rates in relation to groundwater level in a peat soil under grassland. Biol Fert Soils 39:329-336
Van Beek CL, Droogers P, Van Hardeveld HA, Van den Eertwegh GAPH, Velthof GL, Oenema O (2007) Leaching of solutes from an intensively managed peat soil to surface water. Water Air Soil Pollut 182:291-301

Van den Hurk B, Klein Tank A, Lenderink G, Van Ulden A, Van Oldenborgh GJ, Katsman C, Van den Brink H, Keller F, Bessembinder J, Burgers G, Komen G, Hazeleger W, Drijfhout S (2006) KNMI climate change scenarios 2006 for the Netherlands KNMI scientific report WR 2006012006

Van Dijk J, Stroetenga M, Bos L, Van Bodegom PM, Verhoef HA, Aerts R (2004) Restoring natural seepage conditions on former agricultural grasslands does not lead to reduction of organic matter decomposition and soil nutrient dynamics. Biogeochemistry 71:317-337

Van Drecht G, Reijnders HFR, Boumans LJM, Van Duijvenboden W (1996) De kwaliteit van het grondwater op een diepte tussen 5 en $30 \mathrm{~m}$ in Nederland in het jaar 1992 en de verandering daarvan in de periode 1984-1993. RIVM report 714801005, Bilthoven

Van Mossevelde T, Schipper PNM, Bogaard FC (2005) Kwaliteitsaspecten infiltreren stedelijk water beter bekeken Fase 1: beschikbare kennis en ervaring. STOWA report 2005-23, Utrecht

Van Oene H, Burgerhart N, Berendse F (2001) Inundation of reclaimed fen areas reduces greenhouse gas emissions and creates new nature reserves. Change 59:12-14

Van Ouwerkerk RJW, Tijsen RJ (2005) Negen waterbalansen binnen het gebied's Gravelandsevaartboezem, een bundeling van notities. Internal Report Dienst Waterbeheer en Riolering, Hilversum

Verhoeven JTA (1992) Fens and bogs in The Netherlands, vegetation, history, nutrient dynamics and conservation. Kluwer, Dordrecht. Geobotany 18

Verhoeven JTA, Setter TL (2009) Agricultural use of wetlands: opportunities and limitations. Ann Bot doi:10.1093/aob/ mcp 172

Verhoeven JTA, Arheimer B, Yin C, Hefting MM (2006) Regional and global concerns over wetlands and water quality. Trends Ecol Evol 21:96-103

Vermaat JE, Goosen H, Omtzigt N (2007) A multivariate analysis of biodiversity patterns in Dutch wetland marsh areas: urbanisation, eutrophication or fragmentation? Biodiv Conserv 16:3585-3595

Vermaat JE, Vigneau N, Omtzigt N (2008) Viability of metapopulations of wetland birds in a fragmented landscape: testing the key-patch approach. Biodiv Conserv 17:22632273

Vernooij MGM, Vermaat JE (2009) What happens if we stop pumping? Water level rise in 5 Dutch polders (In Dutch). Landschap 26:57-65

Witteveen Bos (1999) Verdrogingsbestrijding Noord-Hollandse Vechtplassen. Consultancy report for water board Dienst Waterbeheer en Riolering, Hilversum

Zak D, Gelbrecht J, Steinberg CEW (2004) Phosphorus retention at the redox interface of peatlands adjacent to surface waters in northeast Germany. Biogeochemistry 70:357-368 